\title{
A bid for scientific greatness
}

The historic dependence of Japan on other people's ideas has served it well, but cannot continue. The government's determination to boost fundamental research seems likely to encourage a cultural shift, despite the obstacles.

JAPAN has done something remarkable. At a time when science in many other countries is under increasing pressure to deliver applications or to meet strategic socio-economic objectives, the Japanese government has committed itself to substantial acrossthe-board increases in support for basic research in its universities and government research institutes (see page 105). The fact that the Ministry of Finance has accepted the planned 50 per cent increase in government outlays for science and technology to $¥ 17,000$ billion (US $\$ 155$ billion) over the next five years is little short of astonishing, given the relatively poor state of the nation's finances. Is it all too good to be true?

Where the money will come from remains to be decided. But the signs are that funding for public works projects, which helped to prop up the former regime of the Liberal Democratic Party for 38 years, will be reduced, and next year's increase in the consumption tax (from 3 per cent to 5 per cent) will also help. Moreover, past experience with long-term government research projects suggests that the government is more likely than most to live up to its commitment. Some caution is due, given that the finance ministry bitterly resisted setting the target. It may still try to find some devious way to boost the figures temporarily - perhaps with one-off supplementary budgets of the kind seen in recent years - rather than provide a sustained growth of support.

But the Science and Technology Agency clearly expects a longterm and substantial improvement in its budget with its extraordinarily ambitious plan to spend $¥ 2,000$ billion on brain research over the next 20 years, or ten times the present level of funding. No doubt other science-related ministries and agencies will deliver equally ambitious plans over the next few weeks as the time for next year's budget proposals at the end of August approaches.

A cynical Western view of all this would be that Japan is at last going to start paying its fair dues and make a contribution to basic research proportional to its economic might. That view is justified: a cool look at the figures shows that Japan is aiming only to bring its spending up to a level comparable to that of advanced Western nations. But the growth required suggests that Japan's publicly funded researchers can look forward to a more fulfilling climate than that facing many of their Western colleagues.

Japan's policy-makers want to boost all areas of science, not only to strengthen the country's future economic base but also to energize its fundamental innovative capacity. They see that although Japan achieved economic success with its cars, electronic consumer goods and computer chips in the 1970s and 1980s, the country has now been left behind in many newly emerging areas of technology, such as biotechnology, gene therapy and software for computer networks, that came out of innovative basic research laboratories of the West. They lament Japan's lack of Nobel prizes and are concerned that the present education system in both schools and universities stifles creative thinking, and they worry that young people are turning their backs on careers in science and engineering. Their aim is to invigorate the university and government research system as a whole and not just to target strategic areas.

It will take a lot more than mere money to achieve this. The five-year plan, for example, also calls for dramatic reforms in employment practices to introduce limited-term contracts for gov- ernment researchers instead of always guaranteeing lifetime employment. Accompanying this will be more assessment of individual scientists and expansion of competitive research grants, expanded employment of foreign scientists, increased numbers of technicians, and a doubling in the number of postdoctoral fellowships. There is no doubt that extensive changes lie ahead, although pockets of dead wood and inbreeding will inevitably persist in research departments for quite some time.

One important element is still missing. Japan does not have a government body that can take an independent view of the various science-related ministries and agencies. But moves are afoot to establish such an organization modelled on the former US Office of Technology Assessment (see Nature 378, 657; 1995). The commitment of Japanese ministries to their plans can be excessive, leading to wasted expenditure. The new independent body is needed to ensure that extra funds for science are sensibly invested.

\section{Crisis not yet over}

Boris Yeltsin's election victory gives Russians a chance, eventually, to believe what they are told.

SHORTLY after the first round of Russia's presidential elections in June, Victor Chernomyrdin, the prime minister, spoke at an awards ceremony at the All-Russian Institute of Experimental Physics in Sarov. His message was reassuring. Following a decree signed two weeks earlier by President Boris Yeltsin, spending on science would be increased to 3 per cent of the federal budget, and all money owed to centres such as that at Sarov would be paid. "The crisis has passed," Chernomyrdin said.

Few Russians these days are prepared to believe much of what they hear from politicians. Nor will many believe that Chernomyrdin's statement was unrelated to his desire to boost Yeltsin's second-round prospects. Nevertheless, there are reasons for Russian scientists to find an element of reassurance in the prime minister's explicit promise of increased support - just as they should, in principle, be relieved by Yeltsin's subsequent victory last week.

Many will have been tempted to vote for Yeltsin's main rival, Gennadi Zyuganov, reflecting their dissatisfaction with the situation facing the scientific community. Over the past four years, many government-financed laboratories have been closed. To the highly qualified researchers who have lost their jobs, a return to the security of the past is understandably attractive.

But there are signs that things are improving. Earlier this year, for example, Boris Saltykov, the minister for science and technology policy, was able to announce that, as a result of salary increases introduced last autumn, the gap between such salaries and the official subsistence level has, at least, stopped increasing.

The difficulties facing Russian science, like the rest of the economy, remain enormous. But at least Yeltsin's victory has left open the doors for reform, including the continued need to increase the flexibility and transparency with which Russian science is run. The West can only hope that his success will have given Yeltsin and his allies the confidence to grasp the nettles that they still face. 